\title{
Pemberdayaan Perempuan Rawan Sosial Ekonomi (Prse) Dalam Meningkatkan Kesejahteraan Keluarga di Kabupaten Bantul Diy Tahun 2013-2018
}

Wina Qurratu A'yun ${ }^{1}$

Administrasi Publik, Universitas Aisyiyah Yogyakarta winaqurratu.30@gmail.com

\section{Nur Faidati ${ }^{2}$}

Administrasi Publik, Universitas Aisyiyah Yogyakarta nurfaidati18@gmail.com

\section{E-ISSN (2721-0642)}

Recieved:

January 32021

Revised:

March 182021

Accepted:

April 122021

Doi Number

https://doi.org/10.37950/ijd.v3i1.83

\begin{abstract}
This study aims to understand the empowerment process of SocioEconomic Vulnerable Women and identify factors that influence the empowerment of socioeconomic vulnerable women in Bantul Regency. This study uses descriptive qualitative. The data were gathered through in-dept interviews and documentation. Informants include PRSE empowerment administrators, PRSE assistants, PRSE members. The results show that there has been success in the process of empowering women with socio-economic vulnerabilities in improving family welfare in Bantul Regency. This is done through training in cooking skills, making snacks, making crafts, and trading. These empowerment activities contribute through empowerment efforts so as to reduce poverty. In addition, there are factors that encourage and hinder the process of empowering women with socioeconomic vulnerabilities. The factors that drive the success of the PRSE program (1) support from family. (2) establishing good cross-sectoral relations. (3) there is a kinship relationship between the management, assistant, and members of the empowerment. (4) budget from the Regional Government, Bantul Regency Social Service especially as empowerment facilitators. Meanwhile, the inhibiting factors are (1) the low quality of Human Resources (HR) in accepting or understanding that community empowerment can support the level of welfare. (2) there is a lack of good time management of women members who are vulnerable to socio-economy in every monthly group meeting.
\end{abstract}

Keywords: community empowerment, socio-economic vulnerable women, family welfare, 


\section{Abstrak}

Penelitian ini bertujuan untuk memahami proses pemberdayaan Perempuan Rawan Sosial Ekonomi (PRSE) dan mengidentifikasi faktor yang mempengaruhi pemberdayaan perempuan rawan sosial ekonomi di Kabupaten Bantul. Penelitian ini menggunakan metode penelitian kualitatif. Teknik pengumpulan data menggunakan wawancara mendalam dan dokumentasi. Informan meliputi pengurus pemberdayaan PRSE, pendamping PRSE, anggota PRSE. Hasil penelitian menunjukkan bahwa proses pemberdayaan perempuan rawan sosial ekonomi dalam meningkatkan kesejahteraan keluarga di Kabupaten Bantul cukup berhasil dilakukan. Hal tersebut dilakukan melalui kegiatan pelatihan keterampilan memasak, membuat makanan ringan, membuat kerajinan, dan berdagang. Kegiatan pemberdayaan tersebut berkontribusi terhadap penurunan angka kemiskinan. Faktor-faktor yang mendorong keberhasilan program PRSE (1) adanya dukungan dari keluarga. (2) terciptanya hubungan relasi antar lintas sektor yang baik. (3) adanya hubungan kekeluargaan antara pengurus, pendamping, dan anggota pemberdayaan. (4) anggaran dari Pemerintah Daerah, Dinas Sosial Kabupaten Bantul khususnya sebagai fasilitator pemberdayaan. Sementara itu faktor penghambatnya adalah (1) rendahnya kualitas Sumber Daya Manusia (SDM) dalam menerima atau memahami bahwa pemberdayaan masyarakat dapat menunjang tingkat kesejahteraan. (2) kurang baiknya manajemen waktu dari anggota perempuan rawan sosial ekonomi di setiap pertemuan kelompok bulanan.

Kata kunci: pemberdayaan masyarakat, perempuan rawan sosial ekonomi, kesejahteraan keluarga

\section{Pendahuluan}

Setiap negara harus berupaya dalam meningkatkan kesejahteraan masyarakat guna mencapai pertumbuhan ekonomi yang seimbang dan dapat mengikuti kemajuan di negara lain. Negara dikatakan tidak mengalami kemajuan apabila adanya permasalahan ketimpangan sosial masih menjadi krusial dan harus segera diselesaikan. Ketimpangan sosial merupakan keadaan dimana tidak adanya kesetaraan dalam kehidupan sosial bermasyarakat, sehingga dengan keadaan seperti itu maka akan terjadi perbedaan status sosial. Hal ersebut akan berpengaruh pada permasalahanpermasalahan sosial lainnya seperti penggangguran, tindak kriminal semakin meningkat, serta dapat mempengaruhi angka kemiskinan. Selain itu, kemiskinan juga dapat mengakibatkan rendahnya rasa ketidakberdayaan, yang mana ketidakberdayaan ini akan mempengaruhi tingkat kesejahteraan sosial di dalam masyarakat. Seperti halnya, kondisi PRSE yang dapat mempengaruhi pendapatan dalam berumah tangga serta kondisi mental atau psikologis, kondisi sosial tersebut dapat dirasakan tidak secara langsung oleh masyarakat umum.

Menurut Marwati \& Astuti (2011, dalam Purnama, 2018) mengatakan bahwa banyak peneliti kontemporer mengungkapkan, dalam sebuah keluarga miskin, perempuan senantiasa sebagai katup penyelamat bagi perekonomian keluarga. Pemberdayaan masyarakat terutama yang melibatkan perempuan merupakan suatu proses dalam memberdayakan potensi yang ada pada masyarkat. Dengan tujuan untuk memperbaiki kondisi kehidupan yang layak tanpa harus berpangku tangan terhadap bantuan dari pemerintah (Faedlulloh, 2018). Sehingga perempuan mampu menempatkan fungsi sosial dalam pembangunan secara langsung maupun tidak langsung. Pembangunan yang dimaksud adalah berubahnya kualitas kesejahteraan 
sosial khususnya pada peningkatkan pendapatan dalam rumah tangga. Dalam pemberdayaan tersebut dapat mengoptimalkan nilai kreativitas yang menitikberatkan pada Sumber Daya Manusia (SDM) dan meminimalisir dalam penggunan Sumber Daya Alam (SDA) sehingga dapat mewujudkan nilai-nilai yang berkesinambungan.

Tabel 1.3

Persentase Jumlah Penduduk Miskin menurut Kabupaten/Kota di Provinisi D.I. Yogyakarta tahun 2013-2017

\begin{tabular}{cccccc}
\hline Tahun & $\begin{array}{c}\text { Kab. Kulon } \\
\text { Progo }\end{array}$ & Kab. Bantul & $\begin{array}{c}\text { Kab. } \\
\text { Gunungkidul }\end{array}$ & Kab. Sleman & $\begin{array}{c}\text { Kota } \\
\text { Yogyakarta }\end{array}$ \\
\hline 2013 & 21,39 & 16,48 & 21,70 & 9,68 & 8,82 \\
2014 & 20,64 & 15,89 & 20,83 & 9,50 & 8,67 \\
2015 & 21,40 & 16,33 & 21,73 & 9,46 & 8,75 \\
2016 & 20,30 & 14,55 & 19,34 & 8,21 & 7,70 \\
2017 & 20,03 & 14,07 & 18,65 & 8,13 & 7,64 \\
\hline
\end{tabular}

Sumber: Badan Pusat Statistik dalam jurnal Prisca Adi Luckynuari (2019)

Berdasarkan pada tabel di atas menunjukkan bahwa jumlah penduduk miskin di Kabupaten Bantul pada periode tahun 2013-2017 mengalami penurunan yang signifikan dari 16,48\% menjadi 14,07\% atau setara dengan 139.666 jiwa dari total jumlah penduduk Bantul sekitar 992.600 jiwa. Hingga pada tahun 2018 turun sebesar 0,64\% atau di angka 13,43\% setara dengan 134.835 jiwa. Pemerintah Kabupaten Bantul mengelompokkan terdapat tiga persoalan sosial terbanyak yang dihadapi daerahnya, yaitu tingginya angka kemiskinan, anak yang tidak terpelihara dan perempuan korban kekerasan. Dalam upaya membebaskan masyarakat dari belenggu kemiskinan, pihak pemerintah maupun swasta telah melakukan berbagi strategi melalui program yang diberikan secara langsung maupun tidak langsung (Purnamasari \& Ramdani, 2019). Sasaran target dari pengentasan belenggu kemiskinan tersebut, yakni Penyandang Masalah Kesejahteraan Sosial (PMKS) khususnya PRSE.

PRSE adalah perempuan yang menyandang status janda yang kurang berdaya dan tidak mampu memenuhi kebutuhan sandang, pangan, papan. Menurut Dinas Sosial (2015, dalam Fajarwati, Sari \& Soewarno, 2017) mengatakan secara lebih spesifik, PRSE adalah seseorang perempuan dewasa yang belum menikah atau janda yang tidak mempunyai penghasilan cukup untuk dapat memenuhi kebutuhan pokok sehari-hari dengan ciri-ciri perempuan dewasa, belum menikah atau janda (single parent), berusia 1860 tahun dan penghasilan tidak memenuhi kebutuhan pokok sehari-hari. Salah satu daerah yang menjadi sasaran dari program Pemberdayaan PRSE ini adalah Kabupaten Bantul. Kabupaten Bantul dinilai aktif dalam menjalankan program pemberdayaan PRSE sejak tahun 2013, hal tersebut di karenakan masih banyaknya masyarakat khususnya perempuan di Kabupaten Bantul terdaftar sebagai anggota PRSE. 


\section{Tabel 1.4 Jumlah Peserta PRSE PKH kabupaten Bantul per Kecamatan tahun 2013-2018}

\begin{tabular}{|c|c|c|}
\hline A. & TAHUN 2013 & 110 \\
\hline 1 & IMOGIRI & 29 \\
\hline 2 & KASIHAN & 29 \\
\hline 3 & SEWON & 21 \\
\hline 4 & PANDAK & 31 \\
\hline B. & TAHUN 2014 & 140 \\
\hline 1 & BAMBANGLIPURO & 18 \\
\hline 2 & BANGUNTAPAN & 18 \\
\hline 3 & DLINGO & 7 \\
\hline 4 & IMOGIRI & 4 \\
\hline 5 & PIYUNGAN & 3 \\
\hline 6 & KRETEK & 3 \\
\hline 7 & SANDEN & 15 \\
\hline 8 & JETIS & 10 \\
\hline 9 & PLERET & 16 \\
\hline 10 & PAJANGAN & 11 \\
\hline 11 & SEDAYU & 9 \\
\hline 12 & PUNDONG & 16 \\
\hline 13 & PANDAK & 10 \\
\hline c. & TAHUN 2015 & 102 \\
\hline 1 & JETIS & 19 \\
\hline 2 & SEDAYU & 23 \\
\hline 3 & PANDAK & 20 \\
\hline 4 & BAMBANGLIPURO & 16 \\
\hline 5 & PUNDONG & 24 \\
\hline D. & TAHUN 2016 & 163 \\
\hline 1 & KRETEK & 4 \\
\hline 2 & PUNDONG & 30 \\
\hline 3 & PLERET & 26 \\
\hline 4 & SEDAYU & 30 \\
\hline 5 & JETIS & 30 \\
\hline 6 & BAMBANGLIPURO & 34 \\
\hline 7 & PAJANGAN & 9 \\
\hline E. & TAHUN 2017 & 54 \\
\hline 1 & PANDAK & 4 \\
\hline 2 & JETIS & 6 \\
\hline 3 & PUNDONG & 7 \\
\hline 4 & SEDAYU & 22 \\
\hline 5 & BAMBANGLIPURO & 15 \\
\hline F. & TAHUN 2018 & 207 \\
\hline 1 & DLINGO & 37 \\
\hline 2 & IMOGIRI & 29 \\
\hline 3 & JETIS & 30 \\
\hline 4 & KRETEK & 26 \\
\hline 5 & PANDAK & 1 \\
\hline 6 & KRETEK & 29 \\
\hline 7 & PUNDONG & 32 \\
\hline 8 & SANDEN & 23 \\
\hline
\end{tabular}

Sumber: Dinas Sosial, Kabupaten Bantul

Berdasarkan tabel di atas menunujukkan bahwa jumlah anggota PRSE peserta PKH di setiap tahunnya selalu mengalami fluktuatif atau sebuah keadaan yang tidak stabil, yang menunjukkan gejala yang tidak tetap dan selalu berubah-ubah dengan melihat perbandingan setiap tahunnya. Dikarenakan syarat penerima manfaat PRSE PKH sendiri adalah perempuan yang menjadi tulang punggung ekonomi keluarga yang 
tidak setiap tahunnya ada. Berdasarkan temuan di lapangan fluktuatif tersebut dikarenakan adanya masalah sosial seperti pengangguran, kemiskinan, dan kasus perceraian yang terjadi setiap tahunnya sehingga jumlah peserta PRSE PKH mengalami peningkatan, sedangkan jumlah peserta PRSE PKH yang mengalami penurunan setiap tahunnya dikarenakan sebagian penerima manfaat sudah dapat dikatakan mampu secara ekonomi dan dalam satu tahun tersebut tidak menutup kemungkinan perempuan rawan sosial ekonomi tersebut sudah menikah lagi atau tidak menjadi pencari nafkah utama sehingga syarat untuk menjadi penerima manfaat sudah tidak berlaku lagi.

Studi yang mengkaji tentang pemberdayaan perempuan rawan sosial ekonomi untuk mengentaskan kemiskinan dan dapat menyelesaikan masalah ekonomi sosialnya terutama telah banyak dilakukan oleh peneliti sebelumnya. Diantara studi tersebut adalah Mulia Astuti (2012). Mulia Astuti melakukan penelitian terkait pemberdayaan perempuan miskin berbasis pemanfaatan sumberdaya lokal melalui pendekatan sosial entrepreneurship di Kabupaten Pasaman, Sumatera Barat. Penelitian yang lain dilakukan oleh Rahmawati, Dian (2016). Rahmawati Dian meneliti tentang kemitraan antara pemerintah, swasta dan masyarakat dalam menyejahterakan perempuan rawan sosial ekonomi di Desa Sumberejo Kecamatan Batu Kota Batu. Penelitian ini berfokus pada kemitraan antara pemerintah, swasta dan masyarakat dalam menyejahterakan perempuan rawan sosial ekonomi. Studi tentang pemberdayaan perempuan rawan sosial ekonomi juga dilakukan oleh Akhmad Purnama (2018). Akhmad Purnama meneliti tentang pemberdayaan perempuan rawan sosial ekonomi melalui peningkatan kesejahteraan keluarga yang dilakukan di Desa Triwidadi.

Melihat dari uraian dan permasalahan sosial di atas serta masih banyaknya jumlah PRSE peserta PKH di Kabupaten Bantul peneliti tertarik untuk melakukan penelitian tentang Pemberdayaan PRSE Dalam Meningkatkan Kesejahteraan Keluarga di Kabupaten Bantul, Daerah Istimewa Yogyakarta dalam pengentasan kemiskinan. Fokus yang diamati dari penelitian ini adalah bagaimana proses pemberdayaan PRSE peserta PKH itu dilakukan. Lebih lanjut penelitian ini juga akan menganalisis faktor pendorong dan penghambat dari proses tersebut.

\section{Kerangka Teori}

\section{Pengertian Pemberdayaan Masyarakat}

Menurut Anita Fauziah (2009) dalam Evliyani (2017) menyatakan bahwa pemberdayaan dalam oxford English dictionary adalah terjemahan dari kata empowerment yang mengandung dua pengertian: (1) to give power to (memberi kekuasaan, mengalihkan kekuatan atau mendelegasikan otoritas pada pihak lain, (2) to give ability, enable (usaha untuk memberi kemampuan). Dengan dilakukannya pemberdayaan masyarakat yang dapat dikatakan dalam kelompok masyarakat yang tertinggal dengan kondisi sosial ekonominya dapat diwujudkan dan terlibat dalam pembangunan secara terbuka dan partisipatif yang berdasarkan dalam pemenuhan kebutuhan masyarakat itu sendiri sehingga kelompok tersebut mampu berkembang dan dapat mencari solusi atas suatu permasalahannya sendiri. Serta selalu melibatkan masyarakat dalam membangun kemitraan dengan tujuan untuk meningkatkan kekuatan atau keberdayaan suatu masyarakat yang sering dianggap lemah dan terbelakang (Pathony, 2019). Lebih lanjut lagi mengenai kondisi masyarakat yang masih tertinggal harus ditingkatkan kemampuanya dengan mengembangkan potensi serta memberdayakannya agar 
berdaya. Adapun definisi lain menurut Mubyarto (1994, p.204, dalam Sarjito, 2013) menegaskan bahwa pemberdayaan adalah upaya memberi daya kepada masyarakat. Pemberdayaan tersebut tidak hanya berupa bantuan atau pemberdayaan ekonomi masyarakat, akan tetapi lebih berupa tindakan-tindakan nyata yang dapat meningkatkan sumber daya manusia.

Menurut Kartasasmita (1997) disampaikan bahwa pemberdayaan masyarakat adalah upaya untuk memampukan dan memandirikan masyarakat yang dilakukan dengan upaya sebagai berikut: pertama enabling, yaitu menciptakan suasana atau iklim yang memungkinkan potensi masyarakat berkembang. Titik tolaknya adalah pengenalan bahwa setiap manusia, setiap masyarakat memiliki potensi yang dapat dikembangkan. Pemberdayaan adalah upaya untuk membangun daya itu dengan cara mendorong (encourage), memotivasi dan membangkitkan kesadaran (awareness) akan potensi yang dimilikinya serta berupaya untuk mengembangkannya. Kedua, empowering, yaitu meningkatkan kapasitas dengan memperkuat potensi atau daya yang dimiliki oleh masyarakat. Perkuatan ini meliputi langkah-langkah nyata seperti penyediaan berbagai masukan (input) serta pembukaan akses kepada berbagai peluang yang dapat membuat masyarakat menjadi makin berdaya. Ketiga, protecting, yaitu melindungi kepentingan dengan mengembangkan sistem perlindungan bagi masyarakat yang menjadi subjek pengembangan. Dalam proses pemberdayaan harus dicegah yang lemah menjadi bertambah lemah, oleh karena kekurangberdayaan dalam menghadapi yang kuat. Melindungi dalam hal ini dilihat sebagai upaya untuk mencegah terjadinya persaingan yang tidak seimbang serta eksploitasi yang kuat atas yang lemah.

\section{Metode Penelitian}

Penelitian ini menggunakan jenis penelitian kualitatif. Menurut Saryono (2010), penelitian kualitatif merupakan penelitian yang digunakan untuk menyelidiki, menemukan, menggambarkan, dan menjelaskan kualitas atau keistimewaan dari pengaruh sosial yang tidak dapat dijelaskan, diukur atau digambarkan melalui pendekatan kuantitatif. Lokasi yang digunakan dalam melakukan penelitian tentang Pemberdayaan PRSE dilakukan di Kabupaten Bantul, mengingat Kabupaten Bantul telah aktif menjalankan program Pemberdayaan PRSE sejak tahun 2013, karena dinilai masih banyak masyarakat khususnya perempuan di Kabupaten Bantul terdaftar sebagai anggota PRSE. Untuk penelitian ini responden tidak semua PRSE secara keseluruhan melainkan PRSE peserta PKH, karena data yang murni PRSE di Kabupaten Bantul belum tersedia.

Penelitian ini menggunakan teknik pengumpulan data berupa wawancara mendalam dan dokumentasi. Wawancara dapat diartikan sebagai proses didapatkannya informasi detail antara peneliti dan informan yang tidak bisa didapatkannya melalui dokumentasi. Informan dalam wawancara ini adalah Dinas Sosial Kabupaten Bantul, PRSE Peserta PKH dan Petgas PRSE Kecamatan. Melalui metode dokumentasi, peneliti gunakan untuk menggali data berupa dokumen pendukung yang terkait dengan proses pemberdayaan PRSE, diantaranya adalah website, artikel, data kemiskinan, Peraturan Perunsang-undangan/regulasi, dan foto dokumentasi wawancara.

Dalam penelitian ini, teknik analisis data yang digunakan adalah model interaktif. Analisis data kualitatif yang akan diterapkan peneliti mengacu pada konsep 
analitik Miles dan Huberman (2007, dalam Sarjito, 2013). Tahapan dalam interactive model adalah pengumpulan data, reduksi data, penyajian data, dan penarikan kesimpulan.

\section{Hasil dan Diskusi}

\section{Proses Pemberdayaan Perempuan Rawan Sosial Ekonomi dalam Meningkatkan Kesejahteraan Keluarga}

Pemberdayaan masyarakat sejatinya ialah menciptakan kesejahteraan dan memampukan masyarakat untuk bertahan di tengah kondisi yang masih kurang dari segi keterampilan, pemahaman, serta kesadaran. Peningkatan inventivitas di dalam masyarakat miskin dalam melihat peluang ekonomi dapat didasari dengan bagaimana tindakan pemerintah secara nyata dapat membangun sumber daya manusia dengan kualitas yang memiliki tingkat kesadaran yang kuat. Maka, peningkatan kualitas tersebut baiknya masyarakat tidak hanya dijadikan objek dalam proses pembangunan ekonomi, tetapi merupakan subjek yang melibatkan masyarakat untuk upaya pembangunan ekonominya sendiri (Rasyid \& Dulkiah, 2020). Berikut upaya yang dilakukan Dinas Sosial Kabupaten Bantul dalam memampukan dam memandirikan masyarakat:

Pertama, enabling yaitu menciptakan suasana atau iklim yang memungkinkan potensi masyarakat berkembang. Dalam upaya tersebut Dinas Sosial Kabupaten Bantul telah melakukan pengembangan kemampuan pada PRSE peserta PKH melalui pemberian modal tambahan serta diberikannya pelatihan keterampilan satu bulan sekali seperti pelatihan memasak, pelatihan membuat makanan ringan, membuat kerajinan, dan berdagang. Selain itu, guna menunjang kesadaran terhadap kondisi PRSE peserta PKH pihak Dinas Sosial Kabupaten Bantul juga memberikan edukasi tentang pendidikan pola asuh anak, edukasi mengenai kesehatan gizi balita dan ibu hamil, serta edukasi mengenai bagaimana cara merawat lansia dengan baik. Dimana edukasi-edukasi tersebut diberikan oleh Pendamping pemberdayaan PRSE peserta PKH yang berkompeten dan telah dibekali ilmu dari Pendidikan dan Pelatihan (Diklat). Untuk lebih mengoptimalkan potensi pada masyarakat khususnya PRSE peserta PKH, Dinas Sosial Kabupaten Bantul menjalin kerjasama antar instansi lain untuk berpartisipasi dalam membebaskan masyarakat atas belenggu kemiskinan. Instansi lain tersebut seperti, Dinas Koperasi Usaha Kecil Menengah dan Perindustrian (KUKMP), Dinas Pertanian, Dinas Koperasi, Usaha Ekonomi Produktif Bantuan Keuangan Khusus (UEP BKK). Dengan adanya upaya enabling atau suasana mengembangkan potensi yang ada di masyarakat dengan bimbingan teknis tersebut dapat meningkatkan pola pikir perempuan rawan sosial ekonomi sehingga dapat memunculkan ide-ide kreatif atau inovatif mengenai usaha dan potensi yang mereka miliki. Serta menumbuhkan rasa kesadaran bahwa orangyang terlahir dengan ekonomi yang rendah akan dipandang sebagai kelompok lemah.

Kedua, empowering yaitu mengoptimalkan kapasitas potensi yang ada di dalam masyarakat. Dalam melaksanakan proses pemberdayaan Dinas Sosial perlu melibatkan beberapa mitra kerja dari luar Dinas Sosial dengan tujuan dapat membuka akses peluang terhadap PRSE sehingga dapat menunjang kualitas sumber daya manusia dalam hal kemampuan, berpikir, serta keterampilan untuk mengantisipasi tuntutan di masa yang 
akan datang. Berdasarkan penelitian yang telah dilakukan, menunjukkan bahwa pengoptimalan yang dilakukan oleh Dinas Sosial, yaitu dengan mengajukan anggota pemberdayaan yang telah berhasil dan konsisten dalam menjalankan usahanya selama satu tahun melalui Usaha Ekonomi Produktif (UEP) PKH guna anggota pemberdayaan tersebut dapat melebarkan sayapnya secara kualitas dan kuantitas dalam memperbaiki keadaan status sosialnya (Solikhin, 2017). Dengan bekal wawasan yang telah mereka dapatkan akan menumbuhkan jiwa entrepreneurship yang begitu kuat dalam dirinya sehingga mampu meningkatkan keberdayaan kaum PRSE di Kabupaten Bantul.

Ketiga, protecting yaitu melindungi dan menyelamatkan kepentingan masyarakat penyandang masalah kesejahteraan sosial. Dinas Sosial Kabupaten Bantul melindungi kepentingan atau usaha yang sedang dijalankan oleh penerima manfaat melalui tindakan pemantauan atau monitoring yang dilakukan oleh pendamping anggota pemberdayaan PRSE peserta PKH tiap triwulan atau tiga bulan secara berturut-turut. Karena dengan pemanatauan atau monitoring tersebut untuk mengetahui apakah usaha yang dijalankan telah berjalan sesuai dengan rencana dan apakah ada kendala-kendala dalam menjalankan usahanya sehingga pendamping perlu menyesuaikan untuk perbaikan kendala atau hambatan yang ada. Dalam proses pemberdayaan sangat diperlukannya upaya perlindungan dikarenakan harus membangun kebersamaan serta keadilan antara yang sudah berjalan usahanya dengan yang belum berkembang.

\section{Pemberdayaan PRSE dalam Meningkatkan Kesejahteraan Keluarga}

Pemberdayaan perempuan yang dilakukan oleh Dinas Sosial Kabupaten Bantul melalui beberapa tahapan atau upaya sejauh ini telah berdampak positif dalam menciptakan perempuan rawan sosial ekonomi peserta $\mathrm{PKH}$ menjadi lebih berdaya. Salah satu kunci keberhasilan dalam implementasi sebuah program/ kebijakan adalah adanya kerjasama/ kolaborasi antar aktor untuk mengatasi masalah keterbatasan yang dihadapi oleh implementor (NF Mutmainah \& GK Mahendra, 2019). Hal tersebut ditunjukkan dengan meningkatnya pendapatan sesudah menerima pelatihan dan bantuan berupa modal tambahan melalui program pemberdayaan PRSE peserta PKH. Meningkatnya pendapatan tersebut melalui usaha produktif yang mereka jalankan. Hal tersebut dapat dirasakan oleh penerima manfaat yang awalnya modal hanya pas-pasan sekarang telah lebih dari cukup untuk pemenuhan kebutuhan pokok sehari-hari. Dalam proses pemberdayaan perempuan tersebut yang menjadi syarat penerima bantuan ialah mereka yang telah mempunyai embrio usaha seperti usaha makanan kecil, berdagang, dll. Sehingga, dengan adanya bantuan serta pelatihan-pelatihan yang diberikan oleh Dinas Sosial Kabupaten Bantul dapat merealisasikan penerima manfaat yang lebih produktif dan kreatif dalam memajukan kapasitas diri dan meningkatkan kesadaran.

Berdasarkan informasi yang diperoleh melalui wawancara dengan penerima manfaat mayoritas pendidikan terakhirnya Sekolah Menengah Pertama (SMP). Dengan pendidikan yang tidak tinggi akan berdampak pada minimnya pengetahuan dan kemampuan sehingga belum mampu dalam mengidentifikasi permasalahan sosial yang terjadi. Hal tersebut akan mengakibatkan tingginya angka pengangguran dan berkurangnya tingkat kesejahteraan. Karena orang yang berstatus pengangguran tidak memiliki penghasilan serta akan berpengaruh pada melonjaknya angka kemiskinan. Sebelum menjadi anggota pemberdayaan PRSE peserta PKH tidak sedikit yang belum paham mengenai apa inovasi atau potensi yang mereka miliki. Namun setelah menjadi 
anggota pemberdayaan PRSE peserta PKH adanya peningkatan pemahaman, hal ini ditunjukkan dengan penerima manfaat dapat menjalankan usahanya secara konsisten sehingga dapat mengidentifikasi langkah selanjutanya untuk perkembangan usaha yang sedang mereka lakukan.

\section{Faktor Pendorong dan Penghambat dalam Proses Pemberdayaan Perempuan Rawan Sosial Ekonomi (PRSE) Peserta PKH di Kabupaten Bantul}

Dengan melihat setiap proses pemberdayaan masyarakat khususnya perempuan rawan sosial ekonomi tentu tidak lepas dari faktor pendorong dan penghambat dalam setiap implementasinya. Faktor pendorong merupakan suatu penunjang jalannya kegiatan. Dari hasil penelitian yang telah dilakukan terdapat beberapa faktor pendorong eksternal dan internal. Faktor pendorong eksternal yang dapat memperlancar proses pemberdayaan, yaitu: pertama, motivasi serta dukungan yang diberikan oleh keluarga kepada PRSE peserta PKH. Kedua, adanya hubungan relasi antar lintas sektor yang baik seperti Dinas Koperasi Usaha Kecil Menengah dan Perindustrian (KUKMP), Dinas Pertanian, Dinas Koperasi, Usaha Ekonomi Produktif Bantuan Keuangan Khusus (UEP BKK), Usaha Ekonomi Produktif Program Keluarga Harapan (UEP PKH). Selain adanya faktor pendorong eksternal yang disampaikan oleh informan, ada juga faktor pendorong internal yang mempengaruhi keberhasilan program pemberdayaan PRSE peserta PKH tersebut. Faktor pendorong internal diantaranya adalah terciptanya hubungan kekeluargaan antara pengurus, pendamping, serta anggota pemberdayaan perempuan rawan sosial ekonomi sehingga dapat menumbuhkan rasa kepercayaan, kebersamaan, dan saling tolong-menolong dan anggaran dari Pemerintah Daerah, Dinas Sosial Kabupaten Bantul khususnya sebagai fasilitator bagi para perempuan rawan sosial ekonomi dalam memberikan pelatihan tata boga dan edukasi mengenai kesehatan dan pendidikan yang diikuti oleh para perempuan rawan sosial ekonomi. Dengan demikian dapat dinyatakan bahwa program tidak akan berjalan sesuai dengan tujuan tanpa adanya faktor pendorong eksternal maupun internal sebagai penunjang keberhasilan.

Selain itu, terdapat beberapa faktor-faktor penghambat dari berjalannya proses pemberdayaan PRSE peserta PKH dalam meningkatkan kesejahteraan keluarga. Faktor penghambat yang menunda suatu keberhasilan yaitu rendahnya kualitas Sumber Daya Manusia (SDM) dalam menerima atau memahami bahwa pemberdayaan masyarakat dapat menunjang tingkat kesejahteraan ekonomi secara mandiri. Hal tersebut ditunjukkan dengan kemampuan dan kemauan setiap anggota pemberdayaan berbedabeda. Di samping itu, kurangnya manajemen waktu oleh perempuan rawan sosial ekonomi di setiap pertemuan kelompok bulanan, dikarenakan harus bekerja atau mengurus anaknya, dan mengurus lansia yang ada di rumahnya. Oleh karena itu, kendala tersebut dapat menjadi faktor penghambat berjalannya pelaksanaan program pemberdayaan perempuan rawan sosial ekonomi di Kabupaten Bantul. Dengan begitu penerima manfaat dapat melewatkan edukasi yang diberikan oleh Pendamping guna menambah wawasan pengetahuan mereka.

\section{Kesimpulan}

Berdasarkan uraian dari hasil penelitian dan pembahasan mengenai proses Pemberdayaan PRSE dalam Meningkatkan Kesejahteraan Keluarga di Kabupaten Bantul yang telah dilakukan, maka peneliti dapat menarik kesimpulan antara lain adalah 
dengan adanya pemberdayaan masyarakat yang diberikan khusus bagi PRSE peserta PKH di Kabupaten Bantul ini masyarakat menjadi terberdayakan. Lebih berdayanya perempuan rawan sosial ekonomi ditunjukkan dengan meningkatnya pendapatan sesudah mendapatkan bantuan program pemberdayaan PRSE peserta PKH. Semakin banyaknya perempuan rawan sosial ekonomi yang sudah dapat dikatakan berdaya dan mampu memenuhi kebutuhan pokok sehari-hari, hal tersebut juga sangat mempengaruhi penurunan angka kemiskinan di Kabupaten Bantul.

Dalam keberhasilan pelaksanaan pemberdayaan PRSE terdapat faktor pendorong eksternal dan internal. Dimana faktor pendorong eksternal berasal dari luar Dinas Sosial seperti halnya adanya motivasi atau dukungan dari keluarga penerima manfaat, serta terciptanya hubungan relasi antar lintas sektor yang baik seperti Dinas Koperasi Usaha Kecil Menengah dan Perindustrian (KUKMP), Dinas Pertanian, Dinas Koperasi, Usaha Ekonomi Produktif Bantuan Keuangan Khusus (UEP BKK), Usaha Ekonomi Produktif Program Keluarga Harapan (UEP PKH). Sedangkan faktor pendorong internal yang berasal dari dalam pemberdayaan masyarakat khususnya bagi perempuan rawan sosial ekonomi, yang mana di dalam kelompok tersebut adanya hubungan kekeluargaan antara pengurus, pendamping, serta anggota pemberdayaan perempuan rawan sosial ekonomi sehingga dapat menumbuhkan rasa kepercayaan, kebersamaan, dan saling tolong-menolong. Serta adanya anggaran dari Pemerintah Daerah, Dinas Sosial Kabupaten Bantul khususnya sebagai fasilitator bagi para perempuan rawan sosial ekonomi dalam memberikan pelatihan tata boga dan edukasi mengenai kesehatan dan pendidikan yang diikuti oleh para perempuan rawan sosial ekonomi.

Sedangkan faktor penghambat dalam proses pemberdayaan perempuan rawan sosial ekonomi adalah rendahnya kualitas Sumber Daya Manusia (SDM) masing-masing penerima manfaat untuk dapat meningkatkan kemandirian mereka secara ekonomi khususnya. Selain itu, faktor penghambat lainnya terkait dengan manajemen waktu perempuan rawan sosial ekonomi yang mana mereka memiliki kesibukan yang bermacam-macam sehingga para penerima manfaat tidak sedikit yang tidak hadir dalam setiap pertemuan kelompok dikarenakan harus bekerja, mengurus anak / lansia, dan lain-lain.

Berdasarkan dari hasil penelitian yang telah dilakukan, maka peneliti memberikan rekomendasi kepada pihak Dinas Sosial dalam menjalankan proses pemberdayaan perempuan rawan sosial ekonomi di Kabupaten bantul hendaknya pemberian materi atau sosialisasi mengenai kewirausahaan ditekankan lagi agar kedepannya menumbuhkan kemampuan dan kemauan para penerima manfaat dalam mengembangkan usahanya dengan ide-ide inovatif. Selain itu, untuk lebih mengoptimalkan proses pemberdayaan peran pengurus dan pendamping yang ada di lapangan diharapkan lebih cermat lagi dalam memberikan dukungan moril maupun dukungan materil. Dengan dukungan tersebut harapan kedepannya dapat membantu penerima manfaat dalam menjaga semangatnya untuk terus meningkatkan atau menjalankan usahanya supaya dapat bertahan sehingga dapat mengurangi angka kemiskinan secara signifikan. Selanjutnya rekomendasi kepada Pemerintah Daerah sebaiknya ikut berpastisipasi dalam melakukan pendampingan dengan tujuan untuk memberikan kekuatan kepada masyarakat yang lemah agar kedepannya lebih berdaya sehinga dapat mendukung pembangunan ekonomi di suatu daerah.

\section{Tentang Penulis}


Wina Qurratu A'yun merupakan mahasiswa pada Program Studi Administrasi Publik Universitas Aisyiyah Yogyakarta.

Nur Faidati merupakan dosen pada Program Studi Administrasi Publik Universitas Aisyiyah Yogyakarta. Pendidikan S1 diselesaikan dari Jurusan Ilmu Pemerintahan Fisipol UGM, pendidikan S2 konsentrasi Politik Lokal diselesaikan dari Departemen Politik dan Pemerintahan Fisipl UGM. Mempunyai cukup banyak pengalaman penelitian di Papua, dan memiliki ketertarikan/minat yang besar pada masalah-masalah pembangunan daerah, perencanaan daerah, kebijakan dan keuangan daerah.

\section{Ucapan Terimakasih}

Terima kasih kepada Program Studi Administrasi Publik Universitas Aisyiyah sehingga penelitian sebagai persyaratan tugas akhir telah terselesaikan dan naskah publikasi ini sebagai bagian dari kelengkapan tugas akhir juga sudah terselesaikan.

\section{References}

Agung Sarjito. (2013). Pemberdayaan Perempuan Untuk Meningkatkan Ekonomi Keluarga Melalui Kelompok Petani Kecil (KPK) Ngudi Lestari di Mendongan Bandung Playen Gunung Kidul Yogyakarta.

Faedlulloh, D. (2018). BUMDes dan Kepemilikan Warga: Membangun Skema Organisasi Partisipatoris. Journal of Governance, 3(1), 1-17. https://doi.org/10.31506/jog.v3i1.3035

Fajarwati, Alia. Puspita, Eva Latifah. Sari. Soewarno, Nirani Galuh Putrie. (2017).

Strategi untuk Mengatasi Permasalahan Wanita Rawan Sosial Ekonomi (WRSE).

Majalah Geografi Indonesia, Vol. 31, No. 1. Universitas Gajah Mada dan Ikatan Geografi Indonesia (IGI).

Luckynuari, Prisca Adi. (2019). Analisis Pengaruh Kemiskinan, Pengangguran dan Pertumbuhan Ekonomi Terhadap Kualitas Pembangunan Manusia. Journal of Economics, Vol. 1, No. 1. Universitas Diponegoro.

Mutmainah, Nur Fitri., \& Mahendra, Gerry Katon. (2019). Collaborative Governance Program GenRe Sebagai Upaya Peningkatan Kesadaran Remaja Terhadap Kesehatan Reproduksi di Provinsi DIY. Jurnal Ilmiah Administrasi Publik, Vol 5, No 1.

Mulia Astuti. (2012). Pemberdayaan Perempuan Miskin Berbasis Pemanfaatan Sumberdaya Lokal Melalui Pendekatan Sosial Enterpreneurship.

Pathony, T. (2019). Proses Pemberdayaan Masyarakat Melalui Gerakan Pemberdayaan dan Kesejahteraan Keluarga ( PKK ) di Kabupaten Subang. International Journal of Demos, 1(2), 262-289.

Purnama, Akhmad. (2018). Pemberdayaan Perempuan Rawan Sosial Ekonomi Melalui Peningkatan Kesejahteraan Keluarga. Jurnal PKS, Vol. 17, No. 4.

Purnamasari, H., \& Ramdani, R. (2019). Evaluasi Program Badan Usaha Milik Desa ( BUM DESA ) Oleh Dinas Pemberdayaan Masyarakat dan Desa di Kabupaten 
Karawang. International Journal of Demos, 1(1), 89-100.

Rahmawati, Dian. (2016). Kemitraan antara Pemerintah, Swasta dan Masyarakat dalam Menyejahterakan Perempuan Rawan Sosial Ekonomi (Studi kasus pada Kemitraan PKH di Desa Sumberejo Kecamatan Batu Kota Batu). Universitas Brawijaya.

Rasyid, F. A., \& Dulkiah, M. (2020). Political Will Implementation of The Government in Hope Family Program Policy. Journal of Governance, 5(1), 20-30.

https://doi.org/10.31506/jog.v5i1.7597

Setyawan, 2018, 2, http://bantul.sorot.co/berita, diakses pada tanggal 19 Maret 2020.

Solikhin, A. (2017). Menimbang Pentingnya Desentralisasi Partai Politik di Indonesia. Journal of Governance, 2(1), 36-64. https://doi.org/10.31506/jog.v2i1.2120 